\title{
Food limitation in larval fish: ontogenetic variation in feeding scope and its potential effect on survival
}

\author{
Alexander B. Bochdansky ${ }^{1, *}$, Peter Grønkjær ${ }^{2}$, Pierre Pepin $^{3}$, William C. Leggett ${ }^{4}$ \\ ${ }^{1}$ Department of Ocean, Earth and Atmospheric Sciences, Old Dominion University, 4600 Elkhorn Avenue, Norfolk, \\ Virginia 23529, USA \\ ${ }^{2}$ Department of Biological Sciences, Marine Ecology, University of Aarhus, Finlandsgade 14, 8200 Århus N, Denmark \\ ${ }^{3}$ Northwest Atlantic Fisheries Centre, Department of Fisheries and Oceans, 80 White Hills Road, St. John's, \\ Newfoundland A1C 5X1, Canada \\ ${ }^{4}$ Biology Department, Queen's University, Kingston, Ontario K7L 3N6, Canada
}

\begin{abstract}
We used the radiated shanny Ulvaria subbifurcata as a model species to explore the relative gut fullness from hatch to metamorphosis of wild larvae, and compared these values with those of laboratory-reared larvae fed at maximum rates. Ingestion rates of most wild larvae were above starvation levels but below the maximum feeding levels of laboratory-reared larvae. Twenty-six percent of freshly-hatched wild larvae and $11 \%$ of large, pre-settlement wild larvae had insufficient food in their stomach to satisfy metabolic requirements. These results, taken on their own, are consistent with the much hypothesized increased foraging performance and survival of larger larvae relative to smaller conspecifics. However, feeding scope-defined as the difference between the minimum daily food required for maintenance and the maximum set by gut capacity -increased disproportionately with size during ontogeny. As a result, none of the larger (>500 $\mu \mathrm{g} \mathrm{C}$ ) wild larvae fed at saturating levels. We conclude that environmental factors operating to increase encounters between larvae and prey (e.g. prey densities, turbulence, patch encounter) and ingestion rates will affect smaller and larger larvae differently. As a consequence, increased encounter rates should lead to increased survival in smaller larvae, and (primarily) to increased growth in larger larvae.
\end{abstract}

KEY WORDS: Fish larvae $\cdot$ Feeding $\cdot$ Food-limitation

Resale or republication not permitted without written consent of the publisher

\section{INTRODUCTION}

Two predominant and closely linked factors regulating the intensity of mortality at the larval stage in fishes are food limitation and predation (Leggett \& DeBlois 1994). A definitive assessment of the relative contributions of predation and starvation to the rates of mortality experienced by fish larvae remains elusive because these interacting factors are, in turn, heavily influenced by the environment occupied by the larvae, larval age and size, and the species and specific population examined (Houde \& Schekter 1980, Litvak \& Leggett 1992, McLaren \& Avendaño 1995, Jordaan \& Brown 2003, Hutchings et al. 2007). A more comprehensive and quantitative understanding of when and how food availability and predation interact is key to an understanding of the variations in mortality observed in cohorts of marine fish larvae.

The inability to reliably predict larval fish feeding rates from observed prey abundances in the field is a major obstacle to determining the influence of starvation and food limited growth on larval mortality rates. The fact that no clear relationship between feeding rates and prey levels (i.e. the functional response) has been found partly results from the using inappropriate prey sampling techniques and scales (Frank 1988, de Figueiredo et al. 2005, 2007), but the functional response is also influenced by a multitude of environmental factors, such as light, turbulence and the abundance of predators (MacKenzie et al 1994, Dower et al. 
1997, Puvanendaran \& Brown 1998, Skajaa et al. 2003). Hence, the relationship between prey levels and feeding rates cannot be extrapolated to the field from laboratory experiments (MacKenzie et al. 1990). Consequently, field assessment of prey levels alone is insufficient to determine the extent to which food may or may not be limiting. An alternative approach, the one we chose for our experiments, is to evaluate the gut content of fish larvae as an indicator rather than an absolute measure of feeding success. Allowing fish larvae to feed ad libitum in the laboratory provides information on maximum potential feeding levels. These can then be directly compared to field-collected larvae without the need for assumptions about prey densities and functional responses. This approach has been successfully employed to assess whether growth in juvenile Baltic sprat Sprattus sprattus was food limited (Baumann et al. 2007).

In assessing the importance of resource levels on the growth and survival of fish larvae, a clear distinction must be made between (1) starvation (defined here as consumption less than maintenance), (2) food-limited growth, and (3) maximum growth (characterized by maximum feeding rates in the presence of an overabundance of food, at which point growth rate is regulated primarily by temperature). Starvation has been extensively studied in the laboratory and the field (O'Conell 1980, McGurk 1984, Theilacker 1986, Ferron \& Leggett 1994, Puvanendaran \& Brown 1999, Islam \& Tanaka 2005). Little information exists on the range of conditions under which in situ energy intake exceeds the demands of basic metabolism, but is below satiation. We define this range as the 'feeding scope' in analogy to the well-established metabolic scope (Wieser 1995). Within this feeding scope, food availability is likely to interact heavily with other environmental factors to shape the probability of feeding success and the survival potential of individual larvae. The threshold feeding level for maintenance can be approximated from estimates of routine metabolic rate and provides the lower limit of the feeding scope (Bochdansky \& Leggett 2001). The upper limit, or the maximum potential feeding level, is unknown for most species.

We combined laboratory experiments with field sampling to determine experimentally the maximum feeding levels for a range of sizes of larvae at two representative temperatures, and compared these with feeding levels of wild (field caught) larvae. We used the radiated shanny Ulvaria subbifurcata, a small blennoid species that occurs in coastal waters from Newfoundland to Massachusetts as our model. Individual U. subbifurcata females lay egg masses in nests positioned in crevices and under rocks during a single annual spawning event. Total larval length at hatch is approx- imately $6.5 \mathrm{~mm}$ and larvae start feeding within 24 to $36 \mathrm{~h}$ of hatching. Larvae first appear in Newfoundland waters in June and their abundance peaks in July. In this region, the larvae of $U$. subbifurcata, together with those of capelin Mallotus villosus and cunner Tautogolabrus adspersus, dominate the summer ichthyoplankton (Pepin \& Penney 2000). The biology of U. subbifurcata is well documented in LeDrew \& Green (1975), Green et al. (1987) and Fleming (1999).

\section{MATERIALS AND METHODS}

Laboratory experiments. Egg masses were collected by SCUBA close to field collection Site 2 (Fig. 1). These were incubated individually in well-aerated natural seawater until hatch. Hatching of larvae from a single egg mass typically occurred within a few hours of collection. Larvae from 3 egg masses, all of which hatched within a $36 \mathrm{~h}$ interval, were combined and then evenly distributed into six 57 l glass tanks, each of which received a different food treatment. Larvae were fed freshly-collected wild zooplankton. The average food concentration maintained in each tank was based on nauplius counts (this being the preferred food item, Dower et al. 1998). Prey densities averaged 42 nauplii $\mathrm{l}^{-1}$ in Tank 1, $163 \mathrm{l}^{-1}$ in Tank 2 (reduced to $<100$ in the second week), $400 \mathrm{l}^{-1}$ in Tank 3,646 $\mathrm{l}^{-1}$ in Tank 4, $1065 \mathrm{l}^{-1}$ in Tank 5, and $1254 \mathrm{l}^{-1}$ in Tank 6. These densities were chosen based on prey concentrations provided by Buckley et al. (1993). Tank temperatures were kept at 9 and $14^{\circ} \mathrm{C}$ to match the temperature of surface water during field collections. Surface temperatures in the field ranged from 7 to $13.8^{\circ} \mathrm{C}$ during the first cruise, and from 10.4 to $17.9^{\circ} \mathrm{C}$ during the second. Insufficient larval numbers prevented the execution of a complete functional response experiment at $14^{\circ} \mathrm{C}$. We therefore fed larvae at 2 high feeding levels (1500 and 2600 nauplii $\mathrm{l}^{-1}$ ) to ascertain maximum gut fullness at $14^{\circ} \mathrm{C}$.

Temperatures were maintained within $1^{\circ} \mathrm{C}$ of the 2 target temperatures by immersing the tanks in temperature-controlled baths. An 18:6 h light:dark cycle was maintained to mimic conditions in the field. Fluorescent tubes supplemented with $20 \mathrm{~W}$ halogen lights provided a wide color spectrum for prey detection. The glass tanks were wrapped in black plastic to provide a high contrast background to aid prey detection. Individual larvae were randomly sampled from the tanks using a wide-bore pipette. Only active larvae were sampled. Moribund and dead larvae were removed from the bottom of the tank daily.

The natural zooplankton prey were collected with a $64 \mu \mathrm{m}$ mesh net near station 2 (Fig. 1). The cod-end contents were diluted with natural seawater and trans- 


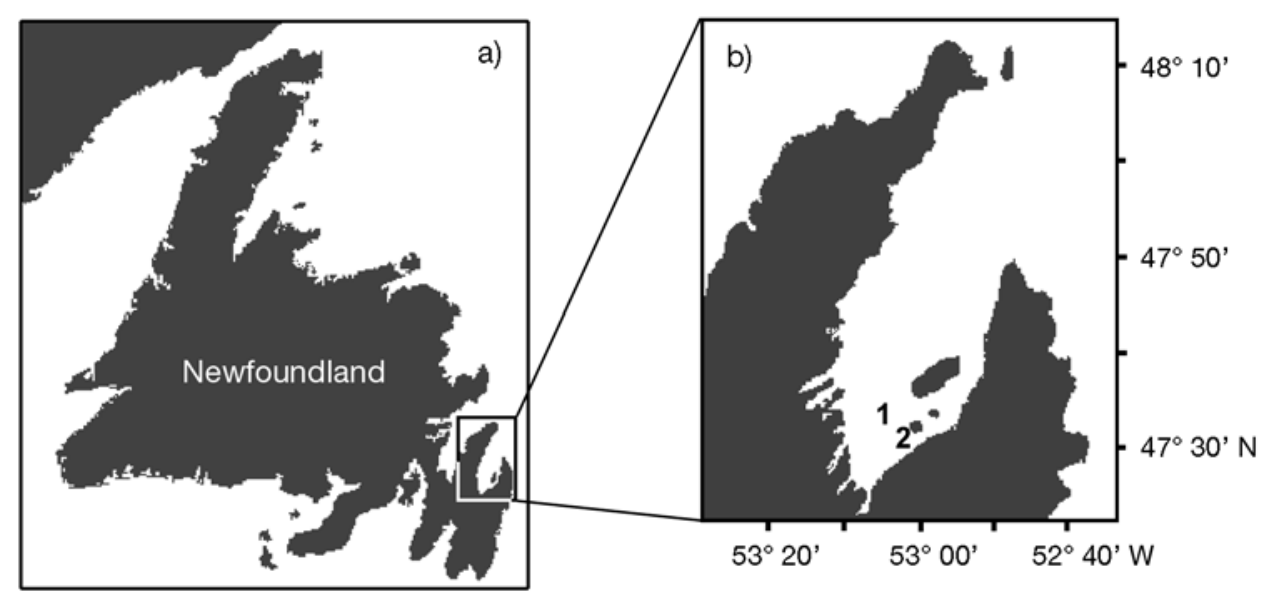

Fig. 1. (a) Island of Newfoundland, eastern Canada. (b) Field collection sites $(1,2)$ in Conception Bay, Newfoundland (summer 1999). June samples were collected at Site 2 (surface temperature: $9^{\circ} \mathrm{C}$ ); July samples were collected at Site 1 (surface temperature: $14^{\circ} \mathrm{C}$ )

ported in an insulated container containing ice packs. In the laboratory, these microzooplankton were maintained in a $100 \mu \mathrm{m}$ plankton net that was suspended in a large drum supplied with running seawater. This stock of zooplankton prey was replenished every 2nd or 3rd day. To eliminate larger predatory zooplankton, we screened each new stock of prey through $300 \mu \mathrm{m}$ Nitex mesh before adding them to the holding net. Repeated sampling showed smaller copepods (e.g. Oithona sp.), copepodites and nauplii to be randomly distributed in the experimental tanks.

Field collections. Wild larvae used to estimate in situ consumption rates were collected at 2 stations in Conception Bay, Newfoundland: at Stn 2 on June 10, 11 and 17 (MV Karl \& Jackie), and at Stn 1 on July 13 and 16, 1999 (CCGS Shamook; Fig. 1). Data from previous studies indicated that these stations yield larvae that are representative of the species assemblage inhabiting Conception Bay (P. Pepin, unpubl. data). Our sampling revealed that larvae of Ulvaria subbifurcata were largely confined to the top $5 \mathrm{~m}$ of the water column This distribution facilitated high frequency, gentle (low speed) collection of larvae.

Wild larvae were sampled between 10:00 and 18:00 h (laboratory reared larvae were also sampled for gut assessments between 12:00 and 17:00 $\mathrm{h}$ to minimize the effect of feeding periodicity on fullness). A drifter consisting of a $10 \mathrm{~m}$ long nylon sleeve $(1 \mathrm{~m}$ diam.) with a weight on the bottom and a buoy fitted with a radar reflector on top was deployed to ensure that we remained within a single larval patch throughout each daily sampling series. Wild larvae were collected with a $1.3 \times 1.2 \mathrm{~m}$ Tucker trawl (500 $\mu \mathrm{m}$ mesh) equipped with an opening-closing mechanism. Wire payout and angle were used to guide the net to the target depth. A Minilog temperature-depth recorder (VEMCO) provided verification of the towing depths and a temperature history for each tow. A microzooplankton net ( $25 \mathrm{~cm}$ diam., $64 \mu \mathrm{m}$ mesh) equipped with a flow meter suspended in the mouth of the Tucker trawl provided simultaneous, quantitative collections of potential prey items. We towed the nets at low speeds $\left(0.5\right.$ to $\left.0.75 \mathrm{~m} \mathrm{~s}^{-1}\right)$ for short periods ( $5 \mathrm{~min}$ ) and used a large cod end (approx. 10 l) to minimize damage to the larvae. CTD casts were performed at the beginning and the end of each sample series. Large gelatinous zooplankton were removed from the samples by gently pouring the contents of the net through a $5 \mathrm{~mm}$ sieve. The samples were then decanted into a $300 \mu \mathrm{m}$ net to remove water before preservation in $95 \%$ ethanol. In the laboratory, larvae were removed from the bulk sample by hand and preserved individually in 95\% ethanol. Microzooplankton samples collected by the $64 \mu \mathrm{m}$ net were fixed in $2 \%$ formaldehyde.

Dissection and analysis. The gut contents of wild and the laboratory larvae were analyzed using identical protocols. Larvae were dissected in drops of distilled water on pre-weighed cover slips. The gut was separated from the body and cut into 3 approximately equal sections. The gut contents were categorized as nauplii, copepodites, cladocerans, and veliger larvae. Individual prey lengths and widths were measured to the nearest $12 \mu \mathrm{m}$. The prosome length of copepodite prey was measured since the urosomes were often missing. For larvae weighing $>1 \mathrm{mg}$, 2 coverslips, one carrying the larva, the other the gut and its contents, were necessary to provide space for dissection. All tissue and gut content remained on the cover slips, which were subsequently dried for $48 \mathrm{~h}$ at $60^{\circ} \mathrm{C}$ and 
transferred to a dessicator before weighing. The cover slips were weighed with a Cahn C-31 microbalance to the nearest $\mu \mathrm{g}$. It was not possible to quantitatively separate gut content from fish tissue. However, inclusion of gut content introduces a non-significant source of error in the determination of fish weight (Bochdansky et al. 2006).

Prey lengths were converted to carbon units using length to dry weight regressions in Klein-Breteler \& Gonzalez (1982) and Uye \& Matsuda (1988) (cited in Mauchline 1998). We used a carbon to dry weight ratio of 0.5 (Conover \& Huntley 1991).

Larval tissue loss due to preservation is size-dependent (Johnston \& Mathias 1993). We corrected for this bias by developing 2 regressions, one relating standard length of live larvae to dry weight of larvae directly transferred to a cover slip, and a second relating standard lengths of live larvae to dry weight of those preserved in ethanol. The difference in the 2 regressions was used to calculate a correction factor for ethanol preservation at various sizes. We verified the accuracy of this factor by comparing the dry weights of groups of freshly hatched larvae of identical size. One randomly selected group was directly transferred onto pre-weighed cover slips, and a second was held in ethanol for several days before transfer to pre-weighed cover slips. For carbon conversions (mg C) from dry weight (mg) of Ulvaria subbifurcata, we used the relationship (Bochdansky et al. 2006):

$$
\begin{gathered}
\text { body carbon }=0.016+0.4 \text { dry weight } \\
\left(\mathrm{r}^{2}=0.989, \mathrm{n}=67\right)
\end{gathered}
$$

Specific consumption rates of wild and laboratoryreared larvae were calculated by dividing the sum of the carbon content of individual prey items in the gut by the carbon content of the larvae and multiplying this by a field-determined, size-dependent gut evacuation rate constant specific to Ulvaria subbifurcata:

$$
r=0.17+0.000126 \times C
$$

where $r$ is the evacuation rate constant $\left(\mathrm{h}^{-1}\right)$ and $C$ the carbon content of the larva $(\mu \mathrm{g})$ (Bochdansky et al. 2006). To determine daily consumption rates, hourly rates were converted using the average photoperiod of $17.5 \mathrm{~h}$ prevailing during the study. The laboratory-derived specific consumption rates for each prey density (at $9^{\circ} \mathrm{C}$ ) were least-square fit to a Michaelis-Menten functional response curve using the Maquardt-Levenberg algorithm. Other non-linear equations (e.g. Ivlev 1961) may arguably provide a more appropriate fit to functional response data, but the Michaelis-Menten equation, with its shallower initial slope, represents a more conservative estimate of saturation. In addition, it allows for comparison of the half-saturation constant $\left(K_{\mathrm{m}}\right)$ frequentlyreported in previous studies. Allometric relationships (specific consumption rates versus body carbon) were examined by Analysis of Covariance (ANCOVA) following $\log _{10}$-transformations. In ANCOVA, a significant interaction term reflects a significant difference in slopes among groups.

Temperatures at the depth of larval collection ranged from 7 to $13.8^{\circ} \mathrm{C}$ during June and 10.4 to $17.9^{\circ} \mathrm{C}$ during late July. Mean temperatures in both the laboratory and the field were centered within these ranges. We therefore made no correction for temperature effects in our comparison of gut fullness of larvae reared the 2 laboratory settings with those of wild larvae. Moreover, because laboratory-reared larvae were fed natural zooplankton, no assumptions about possible compounding effects of diet type were required.

\section{RESULTS}

A size-dependent correction factor for the effect of ethanol $(\mathrm{EtOH})$ preservation was obtained by combining Eqs. (3) \& (4) on the basis of standard length (mm), and solving for dry weight (mg) of fresh larvae:

$$
\begin{gathered}
\text { dry weight }_{[\mathrm{EtOH}]}=0.0019 \times(\text { standard length })^{2.68} \\
\left(\mathrm{r}^{2}=0.83, \mathrm{n}=189\right)
\end{gathered}
$$

and:

$$
\begin{gathered}
\text { dry weight }_{[\text {fresh] }]}=0.0072 \times(\text { standard length })^{2.25} \\
\left(\mathrm{r}^{2}=0.77, \mathrm{n}=39\right)
\end{gathered}
$$

The dry weight corrected for tissue loss in ethanol was then calculated as:

$$
\text { dry weight }_{[\text {fresh] }}=1.39 \text { dry weight }_{[\mathrm{EtOH}]}^{0.84}
$$

Saturated feeding of $5 \mathrm{~d}$ old laboratory-reared larvae was $8.4 \% \mathrm{~d}^{-1}$ of body carbon, and the half saturation constant was 51 nauplii $1^{-1}$ (Fig. 2). Feeding levels were within $10 \%$ of saturation at food concentrations of 400 nauplii $\mathrm{l}^{-1}$ or greater.

Larvae maintained at the lowest prey concentration (42 nauplii $\mathrm{l}^{-1}$ ) died within $8 \mathrm{~d}$ of the initiation of the experiment. When we switched the 2nd tank (originally 163 nauplii $\mathrm{l}^{-1}$ ) to a concentration $<100$ nauplii $\mathrm{l}^{-1}$ to fill in for the missing low concentration treatment, these larvae also died within a week. This indicates that in the laboratory a prey concentration >100 nauplii $\mathrm{l}^{-1}$ is required for maintenance. A MichaelisMenten functional response curve fit to the mean consumption rate data confirmed that prey concentrations $>500$ nauplii $\mathrm{l}^{-1}$ yielded feeding rates near satiation in the laboratory.

To analyse the effect of body size on gut fullness, larvae from tanks containing saturated prey concentrations (>1000 nauplii $\mathrm{l}^{-1}$ ) were grouped into 10 size classes. The upper envelope of the data (reflecting the 
maximum gut content achieved by an individual larva) scaled with body carbon with exponents of 1.34 at $9^{\circ} \mathrm{C}$ and 1.15 at $14^{\circ} \mathrm{C}$ (Fig. 3). The mean gut fullness at saturated feeding levels (lower lines in Fig. 3) scaled with higher exponents $\left(1.51\right.$ at $9^{\circ} \mathrm{C}$ and 1.26 at $\left.14^{\circ} \mathrm{C}\right)$.

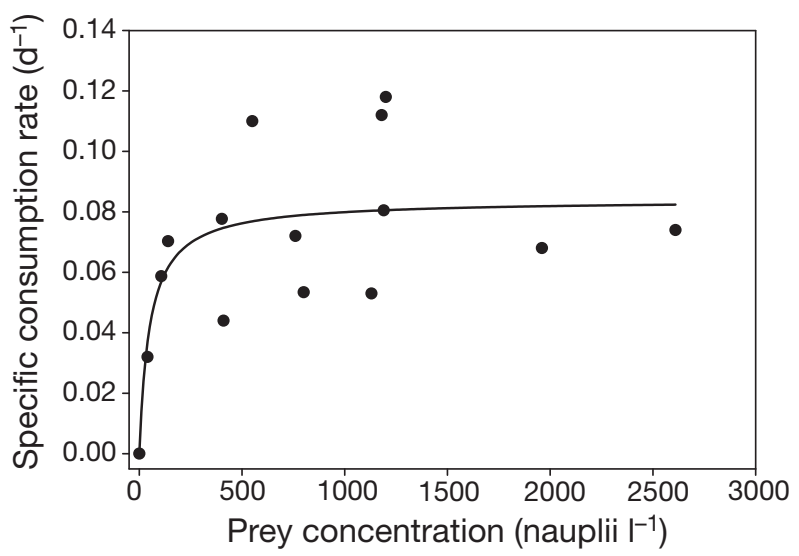

Fig. 2. Ulvaria subbifurcata. Functional response of laboratory reared larvae reared at $9^{\circ} \mathrm{C}$. Each symbol represents the mean of a minimum of 3 and a maximum of 15 larvae. Specific consumption rate: proportion of body carbon. The MichaelisMenten equation for the functional response is:

$$
\mathrm{SPC}=\frac{\mathrm{SPC}_{\max } \times P}{K_{\mathrm{m}} \times P}=\frac{0.084 \times P}{51+P}
$$

where $\mathrm{SPC}=$ specific consumption rate (dimensionless), $P=$ prey concentration (nauplii $\mathrm{l}^{-1}$ ), $\mathrm{SPC}_{\max }=$ maximum specific consumption rate, $K_{\mathrm{m}}=$ half-saturation constant

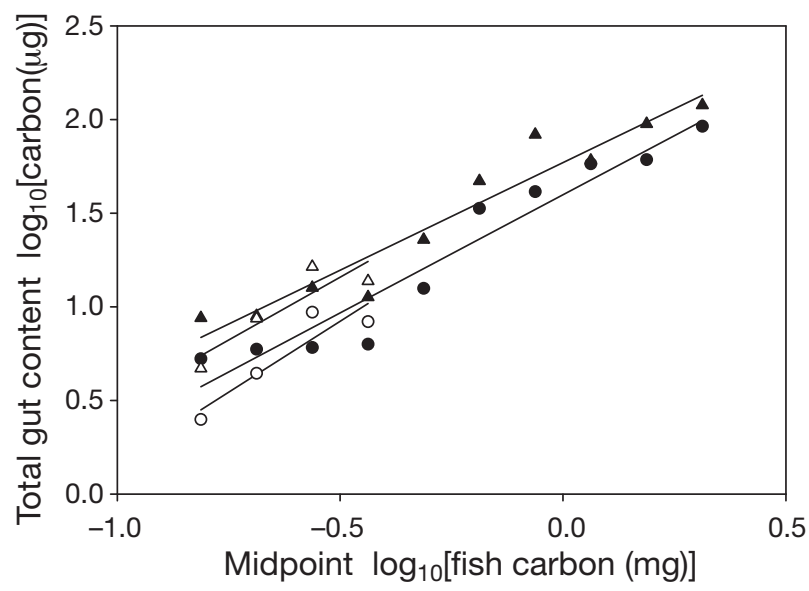

Fig. 3. Ulvaria subbifurcata. Mean (circles) and maximum (triangles) of gut content of laboratory-reared larvae raised at saturated feeding conditions (>1000 nauplii $l^{-1}$ ). Open symbols: $9^{\circ} \mathrm{C}$; closed symbols: $14^{\circ} \mathrm{C}$. The regression equations are: mean at $9^{\circ} \mathrm{C}: y=1.68+1.51 x$, maximum at $9^{\circ} \mathrm{C}: y=1.83+$ $1.34 x_{i}$ mean at $14^{\circ} \mathrm{C}: y=1.60+1.26 x_{i}$ maximum at $14^{\circ} \mathrm{C}: y=$ $1.77+1.15 x$. The slopes represent the allometric scaling exponents. These regression lines were super imposed over field data in Fig. 4

\section{Comparison with field data}

There was no correlation between specific consumption rates of wild larvae and in situ nauplii concentrations, which ranged between 14 and $73 \mathrm{l}^{-1}$ ( $\mathrm{n}=174, \mathrm{r}^{2}=$ $0.000149, p=0.873$ ). At both temperatures studied, the mean gut content of all wild larvae was significantly lower than that of laboratory larvae reared at saturated prey levels (ANCOVA with body carbon as covariate (Fig. 4); $9^{\circ} \mathrm{C}: \mathrm{n}=104, F=34.94, \mathrm{p}<0.0001 ; 14^{\circ} \mathrm{C}: \mathrm{n}=$ $322, F=20.86, \mathrm{p}<0.0001$ ). The slopes (exponents after log-transformation) of the relationships between gut content and body carbon for laboratory and wild consumption rates did not differ significantly at $9^{\circ} \mathrm{C}$ (ANCOVA, homogeneity of slopes, $\mathrm{n}=104, F=1.49$,

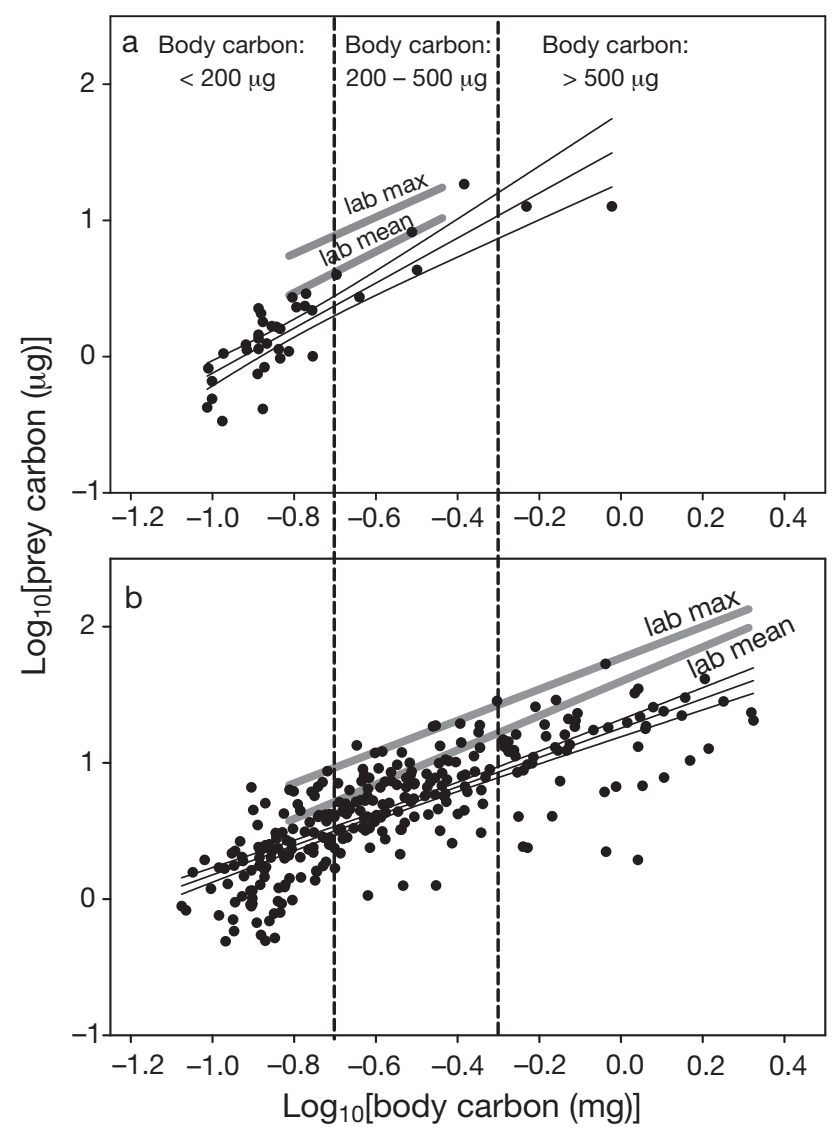

Fig. 4. Ulvaria subbifurcata. Comparison of regression equations for mean (lab mean) and maximum (lab max) gut contents obtained in the laboratory under saturated feeding conditions (transferred from Fig. 3, thick gray lines) and gut content of individual larvae from the field-collections. (a) Samples taken in June at a surface temperature of $9^{\circ} \mathrm{C}$. (b) Samples taken in July at a surface temperature of $14-16^{\circ} \mathrm{C}$. Dashed lines: 200 and $500 \mu \mathrm{g}$ carbon weights along which the sample was split into 3 size classes for Fig. 6. Continuous black lines: lines of the mean gut content of field-collected larvae and their $95 \%$ confidence limits. Dimensions of $x$-axes are 'midpoint $\log _{10}[\text { fish carbon }(\mathrm{mg})]^{\prime}$ 
Table 1. Ulvaria subbifurcata. Specific consumption of laboratory-reared larvae fed at saturated food concentrations (>1000 nauplii $\mathrm{l}^{-1}$ ) at 2 temperatures in comparison to rates for 3 size classes of wild larvae. Consumption is expressed as \% body carbon $\mathrm{d}^{-1}$ $\pm \mathrm{SD}$ (n). n.d.: no data. Laboratory and field values were compared for each size class at each temperature using a Wilcoxon 2-sample test

\begin{tabular}{|llclccc|}
\hline $\begin{array}{l}\text { Size range } \\
(\mu \mathrm{g})\end{array}$ & $\begin{array}{c}\text { Laboratory } \\
9^{\circ} \mathrm{C}\end{array}$ & $\begin{array}{c}\text { Field } \\
9^{\circ} \mathrm{C}\end{array}$ & Wilcoxon & $\begin{array}{c}\text { Laboratory } \\
14^{\circ} \mathrm{C}\end{array}$ & $\begin{array}{c}\text { Field } \\
14^{\circ} \mathrm{C}\end{array}$ & \begin{tabular}{c} 
Wilcoxon \\
\hline$<200$
\end{tabular} \\
\hline $200-500$ & $7.0 \pm 3.4(45)$ & $3.0 \pm 1.6(32)$ & $\mathrm{p}<0.0001$ & $11 \pm 5.4(8)$ & $5.3 \pm 3.2(109)$ & $\mathrm{p}=0.0014$ \\
$>500$ & $9.7 \pm 4.3(22)$ & $8.4 \pm 4.4(5)$ & $\mathrm{p}=0.473$ & $6.2 \pm 4.5(11)$ & $8.1 \pm 4.2(116)$ & $\mathrm{p}=0.256$ \\
& n.d. & $8.4 \pm 1.6(2)$ & - & $23 \pm 9.6(22)$ & $9.1 \pm 5.1(58)$ & $\mathrm{p}<0.0001$ \\
\hline
\end{tabular}

$\mathrm{p}=0.23)$ or at $14^{\circ} \mathrm{C}(\mathrm{ANCOVA}$, homogeneity of slopes, $\mathrm{n}=322, F=2.74, \mathrm{p}=0.099)$. Thus, while the absolute feeding levels differed between laboratory and wild larvae, the allometry of gut content with body weight was preserved.
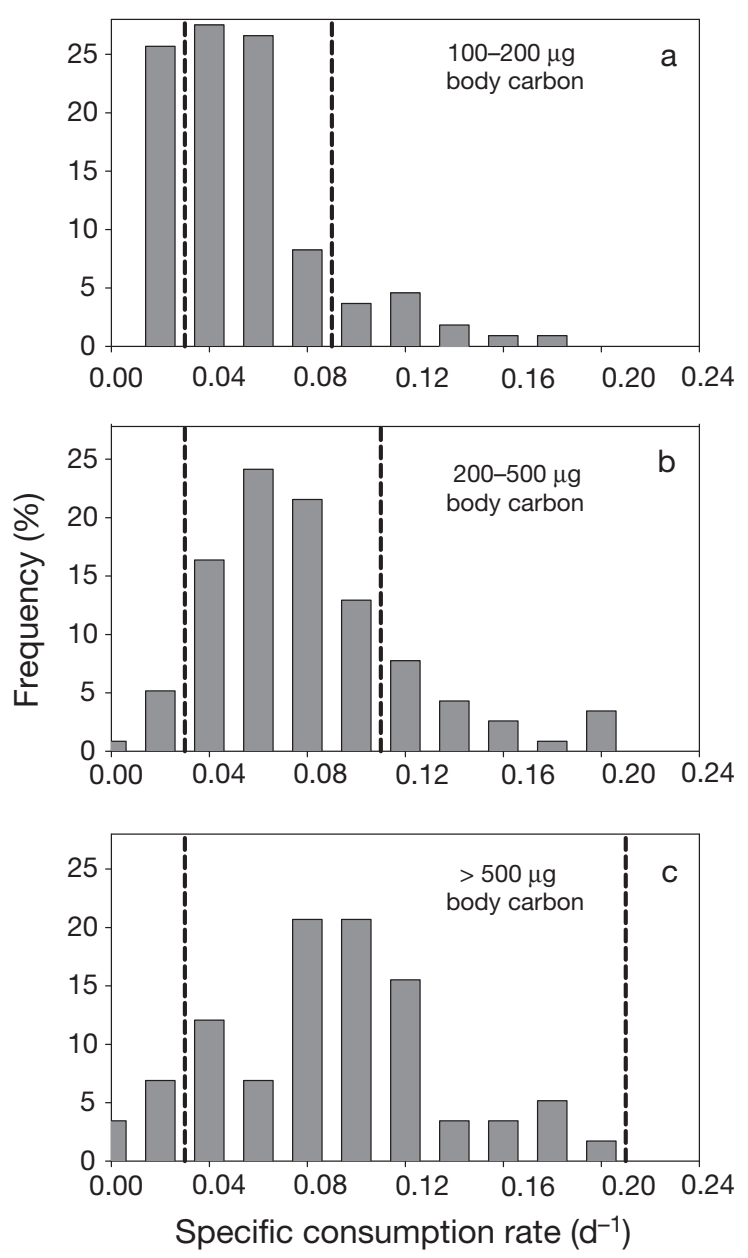

Fig. 5. Ulvaria subbifurcata. Frequency distributions of weight-corrected (specific) consumption rates (proportion of body carbon) for 3 size classes of wild larvae. (a) Body carbon range of <200 $\mu g_{i}$ (b) 200-500 $\mu g_{i}$ (c) $>500 \mu \mathrm{g}$. Dashed lines: maintenance (left) and saturation (right) levels determined in the laboratory. The latter were calculated using the regression equation for saturated feeding at $14^{\circ} \mathrm{C}$ in Fig. 3
On visual inspection, the distribution of residuals about the allometric relationships of gut content with body carbon appeared slightly curved. This suggests that the smallest and the largest larvae may have fed at rates lower than would be inferred from a simple logarithmic relationship (Fig. 4). We therefore divided the wild larvae into 3 size classes $(<200 \mu \mathrm{g}$; 200 to $500 \mu \mathrm{g}$; $>500 \mu \mathrm{g}$ dry weight) to contrast patterns of consumption at three ontogenetic stages (shortly after hatching, at intermediate stages of development, and nearing metamorphosis) with feeding rates of laboratoryreared larvae sampled at similar stages of development. A Wilcoxon 2-sample test that compared the mean consumption rates of each of these 3 broad size classes confirmed this pattern of lower than expected rates in smaller and larger larvae (Table 1). The frequency distributions of weight-corrected (specific) consumption rates for the 3 size classes of wild larvae indicated that relative feeding success increased with size (Fig. 5). While the distribution of consumption frequencies tended toward low consumption levels in small larvae, the distributions became progressively more normally distributed with increasing larval body size (Fig. 5). The lower threshold (dashed lines in Fig. 5) was derived from the mean consumption rates in the laboratory tanks in which none of the larvae survived for more than $8 \mathrm{~d}$ (low prey concentration). Since data on the lower threshold were only available for larvae $<200 \mu \mathrm{g}$, we extrapolated this threshold to the larger larvae based on the finding that there is little change in the weight-specific routine metabolic rate from $200 \mu \mathrm{g}$ to $3 \mathrm{mg}$ (Bochdansky \& Leggett 2001). The upper thresholds were provided by the mean consumption rate of laboratory-reared larvae fed at saturated levels (>1000 nauplii $\mathrm{l}^{-1}$ ).

\section{DISCUSSION}

To date, most field investigations designed to establish a relationship between prey availability, feeding rates and survival in larval fish have been based principally on quantifications of gut content. However, 
such data in isolation are inadequate to reliably detect starvation or food-limited growth. We extended these classical investigations by interpreting gut content data for wild larvae by reference to starvation, foodlimited and maximal feeding rates determined by simultaneously rearing larvae of the same species in the laboratory at equivalent temperatures.

The lower consumption threshold for survival (calculated from the average consumption rate of larvae reared at the lowest food concentration) was $>3.7 \% \mathrm{~d}^{-1}$ of body carbon. This conforms well to minima reported for herring larvae (4\%, Checkley 1984; $2.9 \%$, Kiørboe et al. 1987). The experimentally derived half-saturation constant $K_{\mathrm{m}}$ (the concentration at which ingestion is $50 \%$ of maximum) ranged from 6.6 to $38.3 \mu \mathrm{g} \mathrm{C} \mathrm{l}^{-1}$ (assuming naupliar dry weight ranged from $0.26 \mu \mathrm{g}$ for an average Acartia tonsa nauplius, Durbin \& Durbin 1981; to $1.5 \mu \mathrm{g}$ for a Calanus finmarchicus, Davis 1984). This is consistent with the range of non-saturated food concentrations (5 to $50 \mu \mathrm{g} \mathrm{C} \mathrm{l}^{-1}$ ) reported for 11 species by MacKenzie et al. (1990) and falls within the range reported by Miller et al. (1992). MacKenzie et al. (1990), however, cautioned against translating laboratory functional response data to field situations because larvae achieve saturation at lower prey concentrations in the field. We agree. Our sole purpose in estimating the functional response was to confirm that laboratory-reared larvae achieved maximum feeding rates at prey concentrations of $>1000$ nauplii $\mathrm{l}^{-1}$. We used our laboratory data to determine maximum feeding levels on natural zooplankton prey at temperatures consistent with those prevailing during in situ sampling. This allowed us to compare laboratory measures of maximum gut fullness with the gut contents of wild larvae without reference to the actual shape of the functional response

The in situ feeding rates of wild Ulvaria subbifurcata larvae were generally lower than the maximum feeding rates observed for laboratory-reared larvae (Fig. 4), suggesting that wild larve were food limited. However, the patterns are more complex than simple starvation because only a small percentage of the wild larvae showed signs of severe food limitation. Consistent with the findings of Pepin \& Penney (2000), the gut content of wild U. subbifurcata larvae scaled isometrically with body carbon (Fig. 4). However, wild larvae contained significantly less food than their laboratory-reared counterparts, and only those of intermediate size (200 to $500 \mu \mathrm{g}$ ) achieved rates close to the average saturated feeding potential of laboratoryreared larvae (Fig. 4, Table 1). Peaks in the frequency distributions of specific consumption rates for wild larvae (Fig. 5) revealed a steadily increasing feeding performance with size or ontogeny. Approximately $26 \%$ of the wild larvae in the smallest size class, $6 \%$ of those in the intermediate size class and $11 \%$ of larvae in the largest size class fed at levels below the maintenance threshold. However, this feeding response is more complex than a simple increase in consumption rate with size (Fig. 6). As larvae grew, their feeding scope (i.e. consumption potential) increased as well. This is reflected in the shift to the right of the upper feeding threshold of progressively larger sizes (dashed line in Fig. 5). Thus, while larger larvae were more successful at feeding above the starvation threshold, only a small proportion fed at the maximum levels recorded in the laboratory (Fig. 6). Thorrison (1994), who observed a similar ontogenetic change in gut content as larval cod approached metamorphosis, attributed the outcome to relatively smaller stomachs in metamorphosing larvae. In our study, this outcome could not be related to relative differences in stomach size with ontogeny because our comparisons were between similarly sized laboratory and wild larvae. A similar disclaimer can be made for all size or developmental factors known to have influenced other studies (Jordaan \& Brown 2003). Pepin \& Penney (1997) reported that niche breadth of radiated shanny increases with body size. Munk (1997) similarly found that larval and early juvenile cod prefer prey that are approximately $5 \%$ their length and that a lack of appropriately sized prey decreased juvenile cod stomach content. A relative scarcity of larger food items in the top $5 \mathrm{~m}$ of the water column prior to and during our sampling could have limited the feeding success of large larvae.

Quantitative, laboratory-derived measures of maximum gut fullness of the type we report provide a reliable measure of the physiological maintenance and maximum feeding capacity of larval fishes and offer the potential of providing significant new insights into the consumption rates of fish larvae in the field relative to their maintenance needs and maximal consumption rates that go well beyond the commonly applied qualitative measures (e.g. qualitative stomach fullness). However, several factors, if not controlled or accounted for, can weaken the validity of such comparisons between field and laboratory-derived data such as those we report. First, the use of gut content analysis as a measure of prey consumption rests on the assumption that no food is regurgitated during sampling. Hay (1981) reported significant regurgitation losses in herring larvae. Ulvaria subbifurcata, in contrast, appears to regurgitate little when the gentle collection methods we used are employed (Dower et al. 1998). Only 4 of 322 larvae we collected had empty guts. In this species, this may be a product of the more complex (than herring larvae) S-shaped gut morphology. Second, the visual method we employed to determine the quantity of prey in the guts could result in underestimates of 


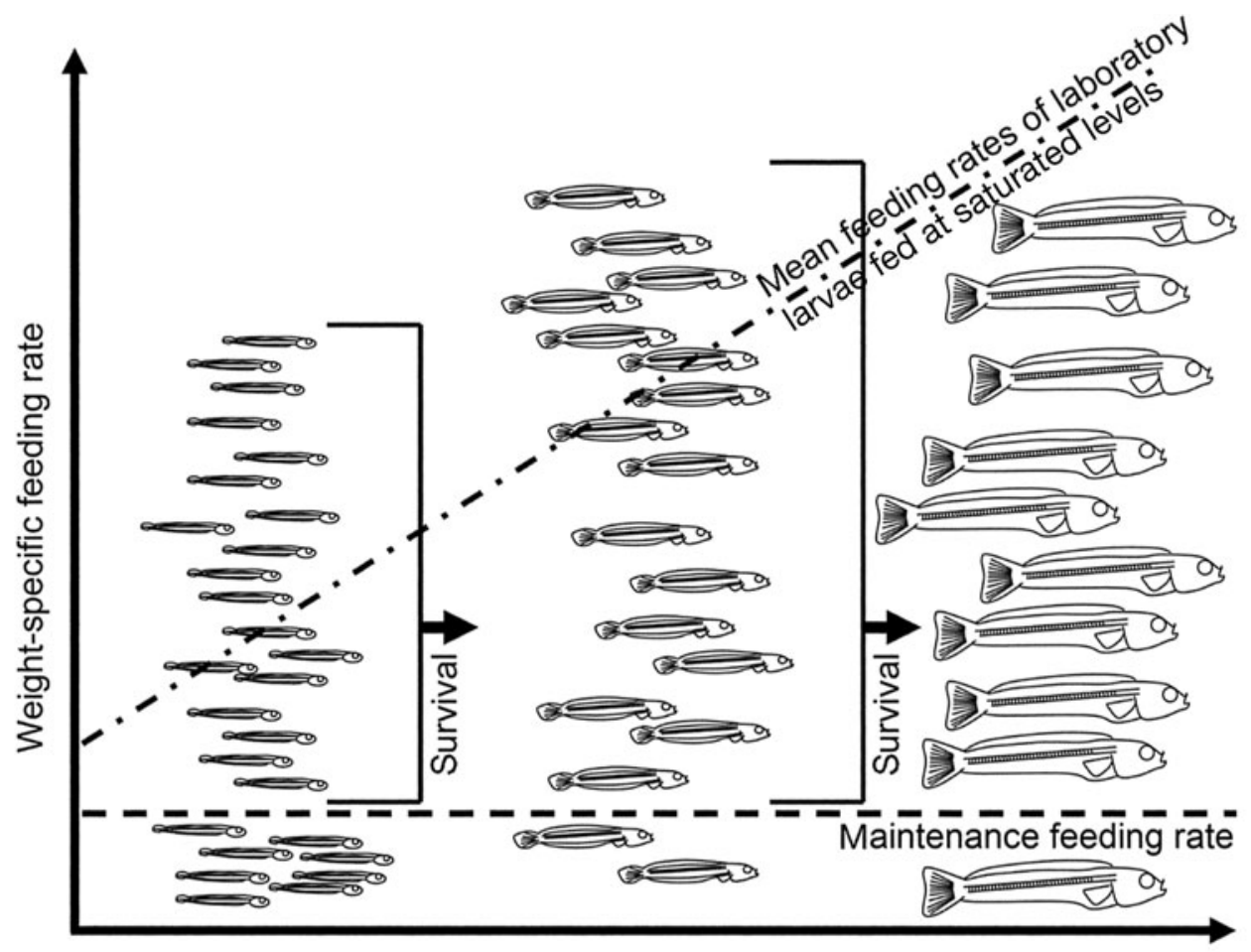

Time

Fig. 6. Ulvaria subbifurcata. Schematic representation of the feeding scope of radiated shannies (area between the dashed and dot-dashed lines) as determined in the laboratory, and superimposed over the observed size-specific consumption rates of wild larvae (fish symbols). Small larvae have a limited weight-specific feeding scope. Their observed feeding levels in the field ranged widely from less than required for maintenance to saturated levels. Fewer of the medium-sized larvae fed at below-maintenance levels in the field but many of them fed at maximum levels. Large larvae seemed to neither starve nor feed at maximum rates in the field when compared to the laboratory. Square brackets enclose larvae that consistently feed above maintenance and survive to reach the next size class

total ingestion because of difficulties in accurately determining the linear dimensions of food fragments. While chitin is not digested efficiently by fish larvae (Conway et al. 1993), some prey items may have shrunk during digestion or their exoskeleton may have been crushed. Failure to adequately detect and quantify prey that lack an exoskeleton may also lead to underestimation of feeding rates. de Figueiredo et al. (2007) argued that ciliates contribute significantly to larval fish diets and help to maintain larvae when metazoan prey availability is low. However, the energetic importance of protozoans is likely to be confined to the earliest life stages and to ensuring the maintenance, but not significant growth, of larvae (van der Meeren \& Næss 1993, Hunt von Herbing \& Gallagher 2000, de Figueiredo et al. 2007). Moreover, Pepin \& Dower (2007) reported that ontogenetic changes in stable isotope levels in radiated shanny are consistent with a diet consisting principally of metazoan prey. Nevertheless, microzooplankton may be important to the feeding dynamics of the smallest larvae, which had the highest percentage of individuals feeding below maintenance as determined by our method.
The frequency distributions of consumption reflected in Fig. 5, and characterized in Fig. 6, may reflect either a distribution of consistently successful versus consistently unsuccessful individuals or, alternatively, a probability function of the foraging success for an individual larva on any given day. The latter interpretation is consistent with the reality that prey distribution is typically patchy on scales from meters to kilometers (Munk \& Kiørboe 1985). Given that feeding has a large environmentally driven stochastic component, it is likely that the frequency distribution shown in Fig. 5 reflects a probability distribution of foraging success. Hence, it is probable that there will always be a small number of larvae at the upper tail of the distribution that feed at high levels because of fortunate coincidence (e.g. Pepin 2004). In the specific case of Ulvaria subbifurcata growing at a rate of 15 to $35 \% \mathrm{~d}^{-1}$, as few as 3 to $5 \mathrm{~d}$ of such growth is sufficient to bring a freshly hatched $100 \mu \mathrm{g}$ larva to a size of $>200 \mu \mathrm{g}$, at which point the probability of feeding success above maintenance and therefore survival, improves greatly (this study, Pepin \& Penney 2000). Large differences in body size at age may therefore be the simple product 
of chance events that convey to a small number of larvae a growth advantage over others.

Larvae of Ulvaria subbifurcata generally had lower than maximal feeding rates in the field, and there was a strong ontogenetic trend in the proportions of larvae characterized as starving, suffering from food limited growth, and feeding at maximal rates. This suggests that increased prey levels are likely to increase the survival chances of both small and large larvae, but through different mechanisms. From this we predict that any environmentally induced increase in the rate of prey encounter will be accompanied by a direct, food-mediated decrease in the mortality rate due to starvation in the smaller size class. A similarly scaled increase in prey encounter rate would affect larger larvae differently because the majority of the larger larvae feed well above maintenance levels. Thus, an increase in prey abundance or encounter rate would not lead to higher survival rates, but to faster growth in these larger individuals instead. Whether faster growth (and larger size at age) increases survival chances continues to be the focus of much debate (reviewed in Leggett \& Frank 2008), and it is not clear that an increase in prey encounter and subsequent increases in feeding rates will yield improved survival in later stage $U$. subbifurcata larvae. For smaller individuals, however, our results suggest that a predationindependent mechanism may explain observed correlations between faster growth and survival (Meekan \& Fortier 1996, Campana 1996). Those smaller individuals for which chance events favor episodes of rapid growth are likely to experience a reduced probability of death by starvation that, in turn, creates a positive survival feedback loop. Given that only 3 studies to date (ours, Folkvord 2005 on cod Gadus morhua, and Baumann et al. 2007 on Baltic sprat) have employed the approach of simultaneous evaluation of feeding rates in situ with maximum feeding rates in the laboratory, it is too early to conclude whether the results we report, and their consequences for growth and survival during ontogeny, can be generalized.

Should the size-dependent shift in the distribution of consumption rates of wild larvae from one characterized by a large proportion of small larvae feeding at marginal rates to one characterized by a larger proportion of larvae feeding at levels judged to be intermediate relative to their potential maximum (see Fig. $5 \& 6$ ) prove to be general, understanding of the importance of food availability to survival and recruitment would be significantly enhanced. Moreover, by conducting such comparisons over a range of environmental conditions and in situ food levels, it should be possible to gain a greater insight into the effects of environmental variability on the feeding, growth and survival potential of larval cohorts than has been possible to date.
Acknowledgements. S. Carter and D. Kay took on the formidable task of dissecting and analyzing the gut contents of ca. 500 fish larvae used in this study. The quality of our data is the product of their tenacity and consistency over a full year of dissections. Thanks go to T. Shears and J. Ryder for laboratory assistance at the Northwest Atlantic Fisheries Center, Department of Fisheries and Oceans, Newfoundland, Canada. N. Brunemeyer and J. Fisher helped with larval collection and maintenance. Zooplankton counts were performed by the staff of the Atlantic Reference Centre, Huntsman Marine Science Centre, in St. Andrews, New Brunswick, Canada. Field sampling benefited from the skills of the crews of the MV 'Karl \& Jackie' (Memorial University) and CCGS 'Shamook' (Canadian Coast Guard). Our collection of egg masses was aided by the Ocean Sciences Centre dive unit (Memorial University of Newfoundland). This research was funded by an operating grant from the National Sciences and Engineering Council of Canada to W.C.L. and a Danish Research Council post-doctoral grant to P.G.

\section{LITERATURE CITED}

Baumann H, Peck MA, Gotze HE, Temming A (2007) Starving early juvenile sprat Sprattus sprattus (L.) in western Baltic coastal waters: evidence from combined field and laboratory observations in August and September 2003. J Fish Biol 70:853-866

Bochdansky AB, Leggett WC (2001) Winberg revisited: convergence of routine metabolism in larval and juvenile fish. Can J Fish Aquat Sci 58:220-230

Bochdansky AB, Bruemeyer ND, Leggett WC (2006) Model evaluation of linear gut evacuation in the larval radiated shanny using a combination of laboratory and field data. Trans Am Fish Soc 135:390-398

Buckley LJ, Smigielski AS, Halavik TA, Burns BR, Laurence GC (1993) Growth and survival of the larvae of three temperate marine fish species at discrete prey densities. II. Cod (Gadus morhua), winter flounder (Pseudopleuronectes americanus), and silver hake (Merluccius bilinearis). In: Walther BT, Fyhn HJ (eds) Physiological and biochemical aspects of fish development. University of Bergen, p 183-195

Campana SE (1996) Year-class strength and growth rate in young Atlantic cod Gadus morhua. Mar Ecol Prog Ser 135: 21-26

> Checkley DM Jr (1984) Relation of growth to ingestion for larvae of Atlantic herring Clupea harengus and other fish. Mar Ecol Prog Ser 18:215-224

Conover RJ, Huntley M (1991) Copepods in ice-covered seas - distribution, adaptations to seasonally limited food, metabolism, growth patterns and life cycle strategies in polar seas. J Mar Syst 2:1-41

Conway DVP, Tranter PRG, Coombs SH (1993) Digestion of natural food by larval and post-larval turbot Scophthalmus maximus. Mar Ecol Prog Ser 100:221-231

Davis CS (1984) Food concentrations on Georges Bank: nonlimiting effect on survival of laboratory reared Pseudocalanus sp. and Paracalanus parvus (Copepoda, Calanoida). Mar Biol 82:41-46

de Figueiredo GM, Nash RDM, Montagnes DJS (2005) The role of the generally unrecognised microprey source as food for larval fish in the Irish Sea. Mar Biol 148:395-404

de Figueiredo GM, Nash RDM, Montagnes DJS (2007). Do protozoa contribute significantly to the diet of larval fish in the Irish Sea? J Mar Biol Assoc UK 87:843-850. 
Dower JF, Miller TJ, Leggett WC (1997) The role of microscale turbulence in the feeding ecology of larval fish. Adv Mar Biol 31:169-220

> Dower J, Pepin P, Leggett WC (1998) Enhanced gut fullness and an apparent shift in size selectivity by radiated shanny (Ulvaria subbifurcata) larvae in response to increased turbulence. Can J Fish Aquat Sci 55:128-142

Durbin AG, Durbin EG (1981) Standing stock and estimated production rates of phytoplankton and zooplankton in Narragansett Bay, Rhode Island. Estuaries 4:24-41

Ferron A, Leggett WC (1994) An appraisal of condition measures for marine fish larvae. Adv Mar Biol 30:217-303

Fleming K (1999) Diel patterns in the feeding ecology of radiated shanny larvae (Ulvaria subbifurcata) from coastal Newfoundland. BSc thesis, Department of Earth \& Ocean Sciences, University of British Columbia, Vancouver

Folkvord A (2005) Comparison of size-at-age of larval Atlantic cod (Gadus morhua) from different populations based on size- and temperature-dependent growth models. Can J Fish Aquat Sci 62:1037-1052

Frank KT (1988) Independent distributions of fish larvae and their prey: natural paradox or sampling artifact. Can J Fish Aquat Sci 45:48-59

Green JM, Mathisen AL, Brown JA (1987) Laboratory observations on the reproductive and agnostic behavior of Ulvaria subbifurcata (Pisces, Stichaeidae). Nat Can 114: 195-202

Hay DE (1981) Effects of capture and fixation on gut contents and body size of Pacific herring larvae. Rapp P-V Reùn Cons Int Explor Mer 178:395-400

> Houde ED, Schekter RC (1980) Feeding by marine fish larvae: developmental and functional responses. Environ Biol Fishes 5:315-334

Hunt von Herbing I, Gallager SM (2000) Foraging behavior in early Atlantic cod larvae (Gadus morhua) feeding on a protozoan (Balanion sp.) and a copepod nauplius (Pseudodiaptomus sp.). Mar Biol 136:591-602

Hutchings JA, Swain DP, Rowe S, Eddington JD, Puvanendran V, Brown JA (2007) Genetic variation in life-history reaction norms in a marine fish. Proc R Soc Lond B 274: 1693-1699

Islam MS, Tanaka M (2005) Nutritional condition, starvation status and growth of early juvenile Japanese sea bass (Lateolabrax japonicus) related to prey distribution and feeding in the nursery ground. J Exp Mar Biol Ecol 323: $172-183$

Ivlev VS (1961) Experimental ecology of the feeding of fishes. Yale University Press, New Haven, CT

Johnston TA, Mathias JA (1993) Length reduction and dry weight loss in frozen and formalin-preserved larval walleye, Stizostedion vitreum (Mitchill). Aquacult Fish Manag 24:365-371

Jordaan A, Brown JA (2003) The risk of running on empty: the influence of age on starvation and gut fullness in larval Atlantic cod (Gadus morhua). Can J Fish Aquat Sci 60: $1289-1298$

Kiørboe T, Munk P, Richardson K (1987) Respiration and growth of larval herring Clupea harengus: relation between specific dynamic action and growth efficiency. Mar Ecol Prog Ser 40:1-10

Klein-Breteler WCM, Gonzalez SR (1982) Influence of cultivation and food concentration on body length of calanoid copepods. Mar Biol 71:157-161

LeDrew BR, Green JM (1975) Biology of the radiated shanny Ulvaria subbifurcata Storer in Newfoundland (Pisces: Stichaeidae). J Fish Biol 7:485-495
Leggett WC, DeBlois E (1994) Recruitment in marine fishes: Is it regulated by starvation and predation in the egg and larval stages? Neth J Sea Res 32:119-134

Leggett WC, Frank KT (2008) Paradigms in fisheries oceanography. Oceanogr Mar Biol Annu Rev 46:331-364

Litvak MK, Leggett WC (1992) Age and size-selective predation on larval fishes: the bigger-is-better hypothesis revisited. Mar Ecol Prog Ser 81:13-24

MacKenzie BR, Leggett WC, Peters RH (1990) Estimating larval fish ingestion rates: Can laboratory values be reliably extrapolated to the wild? Mar Ecol Prog Ser 67:209-225

MacKenzie BR, Miller TJ, Cyr S, Leggett WC (1994) Evidence for a dome-shaped relationship between turbulence and larval fish ingestion rates. Limnol Oceanogr 39:1790-1799

Mauchline J (1998) The biology of calanoid copepods. Academic Press, San Diego, CA

McGurk MD (1984) Effects of delayed feeding and temperature on the age of irreversible starvation and on the rates of growth and mortality of Pacific herring larvae. Mar Biol 84:13-26

McLaren IA, Avendaño P (1995) Prey field and diet of larval cod on Western Bank, Scotian Shelf. Can J Fish Aquat Sci 52:448-463

> Meekan MG, Fortier L (1996) Selection for fast growth during the larval life of Atlantic cod Gadus morhua on the Scotian Shelf. Mar Ecol Prog Ser 137:25-37

Miller TJ, Crowder LB, Rice JA, Binkowski FP (1992) Body size and the ontogeny of the functional response in fishes. Can J Fish Aquat Sci 49:805-812

> Munk P (1997) Prey size spectra and prey availability of larval and small juvenile cod. J Fish Biol 51:340-351

> Munk P, Kiørboe T (1985) Feeding behaviour and swimming activity of larval herring (Clupea harengus) in relation to density of copepod nauplii. Mar Ecol Prog Ser 24:15-21

O'Connell CP (1980) Percentage of starving northern anchovy, Engraulis mordax, larvae in the sea as estimated by histological methods. Fish Bull US 78:475-488

> Pepin P (2004) Early life history studies of prey-predator interactions: a perspective from the larva's point of view. Can J Fish Aquat Sci 61:659-671

Pepin P, Dower JF (2007) Variability in the trophic position of larval fish in a coastal pelagic ecosystem based on stable isotope analysis. J Plankton Res 29:727-737

Pepin P, Penney R (2000) Feeding by a larval fish community: impact on zooplankton. Mar Ecol Prog Ser 204:199-212

Pepin P, Penney RW (1997) Patterns of prey size and taxonomic composition in larval fish: Are there general sizedependent models? J Fish Biol 51:84-100

> Puvanendran V, Brown JA (1998) Effect of light intensity on the foraging and growth of Atlantic cod larvae: interpopulation difference? Mar Ecol Prog Ser 167:207-214

Skajaa K, Ferno A, Folkvord A (2004) Ontogenetic- and condition-related effects of starvation on responsiveness in herring larvae (Clupea harengus L.) during repeated attacks by a model predator. J Exp Mar Biol Ecol 312:253-269

Theilacker GH (1986) Starvation-induced mortality of young sea-caught jack mackerel, Trachurus symmetricus, determined with histological and morphological methods. Fish Bull 84:1-17

Thorisson K (1994) Is metamorphosis a critical interval in the early-life of marine fishes? Env Biol Fish 40:23-36

> Uye SI, Matsuda O (1988) Phosphorus content of zooplankton from the Inland Sea of Japan. J Oceanogr 44:280-286

van der Meeren T, Næss T (1993) How does cod (Gadus morhua) cope with variability in feeding conditions during early larval stages? Mar Biol 116:637-647

Wieser W (1995) Energetics of fish larvae, the smallest vertebrates. Acta Physiol Scand 154:279-290 